\title{
Vennskap i småbarnsavdelinger som private relasjoner på en offentlig arena
}

\author{
Dag Øystein Nome* \\ Universitetet i Agder, Kristiansand, Norge
}

\begin{abstract}
Sammendrag
Denne artikkelen belyser små barns utprøvinger av sitt sosiale handlingsrepertoar basert på mikroetnografiske analyser av videobservasjon fra to norske småbarnsavdelinger. Det tas til orde for å beskrive dette som utprøvinger av rollen som aktør i et offentlig liv og samtidig kunne etablere ulike typer mer private relasjoner med klare grenser mot en felles offentlighet utenfor, og det undersøkes hvordan barn kan mestre kunsten å bevege seg mellom disse to ulike rollene. Artikkelen peker på barnehagen som en særskilt institusjonell kontekst preget av eierløse ting og steder som barna hele tiden må tilegne seg midlertidig bruksrett over. Dette preger hvordan barnas sosiale utprøvinger arter seg. Det innebærer bruk av private gjenstander, invitasjoner hjem til hverandre og ulike måter å beskytte eksklusive relasjoner og aktiviteter på. Denne kunnskapen gjør at begrepet vennskap brukt om barns relasjoner med jevnaldrende ofte innebærer en forenkling av en kompleks sosial virkelighet og hva sosial læring for et liv i institusjon innebærer.
\end{abstract}

Nøkkelord: Toddlere; vennskap; barnehage; barndomssosiologi

\begin{abstract}
This article investigates the development of a social repertoire among toddlers in kindergarten based on micro-ethnographic analysis from two Norwegian kindergarten-groups. This social repertoire includes what is tentatively called the role as part of a public life and the role as part of different private situations, and it shows how a child manages to alternate between these two roles. The article argues that the kindergarten is an institutional context characterized by ownerless things and places by which the children only acquire temporary ownership. This affects how their interactions develop. It includes the use of private things, invitations home, and different ways of protecting their exclusive relationships and activities. Consequently, this finding indicates that the concept of friendship used in their interactions implies a simplification of a complex social reality and what social learning for a life in institutions entails.
\end{abstract}

Keywords: Toddlers; friendship; kindergarten; sociology of childhood

Mottatt: Desember, 2016; Antatt: Januar, 2018; Publisert: Februar, 2018

\section{Introduksjon}

Vennskap og god sosial kompetanse er kjerneverdier i den norske barnehagekulturen. Dette fremgår både i rammeplanen og ved måten mange barnehager presenterer seg

^Korrespondanse: Dag Nome. Universitetet i Agder, Postbok 422, 4604 Kristiansand, E-post: dag. nome@uia.no 
på. Å hjelpe barn til å få seg venner blir derfor ansett som en av nøklene for å forebygge ensomhet, ekskludering og mobbing, men også for å skape god psykisk helse og et godt grunnlag for læring og utvikling (Rammeplan for barnehager, 2017; Kunnskapsdepartementet, 2013; Størksen, 2007). Vektleggingen av vennskap, sosial kompetanse og trygghet i gruppen som aktørene i feltet synes å være opptatt av, gjør det viktig med god kunnskap om hvordan barn orienterer seg sosialt fra starten av sitt institusjonsliv.

Denne mikro-etnografiske undersøkelsen fra to småbarnsavdelinger i Norge bidrar til dette gjennom å utforske ulike kvaliteter ved samspillet blant 2-3-åringene slik de utfolder seg i en norsk institusjonskontekst. Det materialet som presenteres i artikkelen, er i utgangspunktet tolkninger av to ulike episoder, en fra hver av de to barnehagene. Begge episodene involverer de eldste barna i småbarnsavdelingene og kan umiddelbart karakteriseres som utprøvinger av det å væere en venn. Det innebærer at de viser forsøk på å etablere eller forsterke stabile og ofte dyadiske forbindelser.

Artikkelens bidrag er en belysning av hvordan disse første utprøvinger av mer stabile relasjoner arter seg, og hva institusjonskonteksten betyr $i$ disse prosessene. Dette drøftes i lys av barndomssosiologiske og kulturteoretiske perspektiv på barndom i institusjon hvor det særlig påpekes hva barnehage som kontekstuell ramme betyr for barnas identitet, aktørrolle og sosiale handlingsrom (Corsaro, 2014; Ehn, 1983; Gulløv, 1999). Det ligger med andre ord en sosialkonstruktivistisk forestilling til grunn for undersøkelsen.

Annen etnografisk forskning på de yngste barnas sosiale utprøvinger trekkes også inn (Alvestad, 2010; Engdahl, 2011; Greve, 2009; Johansson, 2001; Michélsen, 2004; Nilsen, 2000). Utprøvingene synes å være preget av barnehagens sosialt ustabile karakter som et åpent rom med eierløse ting tilgjengelig for alle, og jeg tar til orde for å karakterisere dette som spenninger mellom å være aktør på en åpen offentlig arena og samtidig kunne etablere og beskytte mer private og eksklusive relasjoner. Refleksjoner omkring hva det er å vere offentlig og hva det er å vare privat i et barnehagerom er derfor sentralt i drøftingen. A vcere offentlig blir forstått som å være tilgjengelig for alle. $A$ vcere privat blir forstått som å bare være tilgjengelig for enkelte utvalgte.

\section{Forskning på relasjonsforhandlinger blant små barn i barnehage}

Helt siden Billy Ehn (1983) gjorde sine første eksplorative studier av livet i barnehagen, har forskningen innen feltet vært opptatt av å forstå hva som skjer når barns aktørrolle som medskaper av sin egen barndom møter barnehagens sterke normative ordenskultur. Eva Gulløv formulerte det slik: «Hvordan opbygger de i samspill betydning og fortolkninger inden for de sociale og kulturelle rammer de er sat i?» (Gulløv, 1999, s. 15), og det har av Randi Dyblie Nilsen blitt kalt «en dialektisk prosess av tilpasning - motstand» (Nilsen, 2000, s. 437). Barns sosiale utprøvinger vil alltid bære preg av den kulturelle konteksten de befinner seg i. For å undersøke hvordan de yngste barnas utprøvinger omkring de første mer stabile relasjonene arter seg, er det derfor visse ting ved dette komplekse institusjonslivet som bør belyses. 
Barnehagen er et sted barna selv ikke har valgt å være. De kan ikke komme og gå når de vil og er derfor prisgitt valgene til både foreldre og det pedagogiske personalet. Disse rammene gir premissene for barnas forsøk på å etablere og vedlikeholde relasjoner seg imellom, med andre ord hvilke og hva slags relasjoner som er mulige å etablere (Markström \& Halldén, 2009, s. 114). Et kjennetegn ved barnehager som har betydning for barnas relasjoner, er alles tilgjengelighet til alt og alle som giør at enhver relasjon eller bruk av ting stadig utsettes for forstyrrelser. Barna må lære å forholde seg til at utstyret, rommet og lekene tilhører allmennheten. De er eierløse, og det forhandles hele tiden om midlertidig eierskap ved å ta det i bruk (Corsaro, 2014, s. 126). Siden det for små barn er en forbindelse mellom å gjøre det samme og å knytte vennskap, er usikkerhet om hvem som har bruksrett til ting og steder med på å gjøre relasjoner sårbare. Corsaro kaller det: «... the fragility of peer interaction, the multiple possibilities of disruption» (2014, s. 158).

Eva Johansson (2001, s. 77) påpeker at det tidlig utvikler seg et sosialt mønster i barnehagen som handler om å vere to når aktiviteter med ting på bestemte steder skal etableres, og at barn nummer tre som nærmer seg en slik aktivitet, ofte opplever at det ikke er plass og dermed avvises. Slike avvisninger som ofte tolkes som lite empatiske og samarbeidsorienterte, er allikevel ifølge Corsaro et uttrykk for en sosial intension fordi: « $\ldots$ the children want to keep sharing what they are already sharing and see others as a threat to the community they have established" (Corsaro, 2014, s. 159). Relasjoner blir sårbare og må både beskyttes og stadig forhandles om (Alvestad, 2010; Engdahl, 2011).

Flere forskere har påpekt at det svært kollektive sosiale livet i barnehagen uunngåelig også preges av ulike typer private leker, selv om disse etter min erfaring ofte er uønsket. Det er påvist at selv de yngste barna kan ha en sterk formening om forskjellen mellom private leker og leker som er felleseide, og de kan utvise stor forståelse for hvordan ulikt eierforhold kan uttrykke seg og respekteres (Johansson, 2001, s. 62). Randi Dyblie Nilsen (2000) har på sin side vist hvordan private leker er en ressurs for barna blant annet i deres motstand mot institusjonens strukturelle kontroll. Nilsen påpeker flere forhold hvor private ting medvirker i barnas ønske om å yte motstand. De kan blant annet unnslippe rydderutiner og alle regler om når og hvor bestemte ting kan brukes. Private leker er unntatt alle slike rammer (Nilsen, 2000, s. 315). Viktigst med hensyn til mine observasjoner er hennes nyansering av den normative antagelsen at barn bruker private leker for å kjøpe seg venner. Det blir en svært reduksjonistisk måte å betrakte barnas sosiale liv på, ifølge Nilsen. Private lekers bidrag i barn-barn-relasjonene er komplekst. De kan brukes som markører knyttet til identitet, men også som nødvendige rekvisitter for å skape og vedlikeholde sosiale relasjoner. Dermed bidrar private ting også til å gi barn kontroll over de sosiale relasjonene sine fordi «... vi kommuniserer via gjenstander. I overført betydning kan gjenstander både bygge gjerder og broer» (Nilsen, 2000, s. 347).

Disse institusjonsspesifikke forholdene bidrar på ulikt vis $\mathrm{i}$ å forme barns måte å være venner på innenfor barnehagens rammer. Vennskap ser med andre ord ut til å være et komplekst fenomen blant små barn fordi det er så kontekstavhengig. I tillegg 
er det grunn til å tro at barnehagepersonalet lett tillegger begrepet vennskap et innhold og et sett forventninger preget av deres egne ulike voksenkontekster, når fenomenet blir satt på dagsorden i barnehagen. Dette er ikke minst aktuelt når stadig flere barnehager gir foreldre det de kaller en vennegaranti ved oppstart i barnehagen (Steenbuch, 2016).

Kan hende er vennskap som analytisk begrep i etnografisk arbeid omkring små barn derfor for upresist å bruke, og det er i den senere tid kommet en del ny barnehageforskning som utfordrer bruken av vennskapsbegrepet (Greve, 2009; Løkken, 2000b; Nilsen, 2000; Øksnes \& Greve, 2015). Det denne forskningen særlig belyser er hva som kjennetegner relasjonene mellom de yngste barna. Disse relasjonene er preget av å gjøre ting sammen eller dele noe i et her-og-nå-perspektiv i et åpent dynamisk barnefellesskap. Slike forbindelser kan være spontane eller planlagte, flyktige eller mer varige, men det som ofte kjennetegner dem, er at barna deler et sted, noe materielt og en aktivitet. Begrepet vennskap i allmenn forstand er derfor lite dekkende fordi det indikerer noe som er statisk og mer kontekstuavhengig (Nilsen, 2015, s. 78). Likevel gir dette samspillet rom for kortere eller lengre emosjonelle kontakter mellom barn, hvor de allerede i sitt andre leveår viser evne til affektiv inntoning og empati (Engdahl, 2011; Howes, 2009). Samspillet kan også ofte være preget av glede og lavt konfliktnivå (Michélsen, 2004). Øksnes og Greve (2015, s. 17) kaller disse relasjonene vennskapshendelser. Randi Dyblie Nilsen introduserer betegnelsen vi-fellesskap om slike situasjonsbestemte vennskapshendelser blant de yngste (Nilsen, 2000, 2015). Gunvor Løkken benytter seg av musikkterminologi når hun beskriver hvordan barna gjennom såkalte flire-konserter toner seg inn på hverandre og danner tuning-in-relationship som om de nærmest vibrerer på samme frekvens (Løkken, 2000a, s. 535). Eva Johannson kaller det «att dela lekvärldar» (Johansson, 2001, s. 72).

Den foreliggende undersøkelsen retter blikket spesielt mot de eldste i småbarnsavdelingen - barn som er omkring tre år gamle - og gjennom mikroetnografiske analyser av samspillet deres i lek viser jeg hvordan barna prøver ut måter å etablere mer stabile relasjoner med noen utvalgte på. I det følgende vil utprøvingene av disse mer stabile relasjonene bli beskrevet. På tross av de nevnte forsøkene på å nyansere begrepsbruken om barnas relasjoner, har jeg i arbeidet med å analysere materialet opplevd at det fortsatt mangler begreper for å kunne beskrive presist nok hva som skjer mellom barna. Artikkelens bidrag vil derfor være å utforske hvordan barns første sosiale utprøvinger av mer stabile relasjoner arter seg, og om dette kan beskrives som et spenningsfelt mellom å opptre på en offentlig arena og samtidig etablere og vedlikeholde private relasjoner.

\section{Metode}

Undersøkelsen er basert på deltagende observasjoner i to barnehagegrupper for barn under 3 år, der det ble gjennomført videoobservasjoner av lek i tillegg til å delta i barnehagens daglige liv i en måned hvert sted. 


\section{Deltagere}

To barnehager deltok i prosjektet. En av barnehagene (BH1) var en tradisjonell avdelingsbarnehage. Den andre barnehagen (BH2) var organisert i baser. Begge gruppene hadde 15 barn og et personale på to pedagoger og to til tre assistenter/ fagarbeidere. Barna var på tidspunktet for observasjonene alle over to år gamle. Det var 8 gutter og 7 jenter i begge gruppene. Det ble ikke innhentet opplysninger om barnas sosioøkonomiske bakgrunn, bortsett fra at fire barn hadde ikke-etnisk-norsk bakgrunn i $\mathrm{BH} 1$ mot to barn i $\mathrm{BH} 2$.

\section{Prosedyren}

Observasjonene ble først gjennomført over en månedsperiode hvert sted, med supplerende observasjoner over en to-ukers periode senere. Det ble gjennomført videoobservasjoner av lek på to ulike tidspunkt i løpet av dagen: først på morgenen når barna ble levert, og siden etter det første måltidet mens barna lekte i påvente av bleieskift og leggetid. Disse tidspunktene ble valgt fordi det var åpne perioder preget av barneinitierte aktiviteter i påvente av faste hverdagssituasjoner eller andre voksenstyrte aktiviteter. Det var alltid en av personalet tilstede på gulvet sammen med barna. I BH1 var alle barna samlet i lekeområdet under observasjonene. I BH2 varierte det med hensyn til hvilke og hvor mange barn som var samlet. Under observasjonene trakk jeg meg tilbake fra aktivt å delta i lek eller rutinesituasjoner for å kunne føre observasjonslogg fra et hjørne i rommet. Det ble for det meste brukt et statisk kamera plassert slik at det sentrale lekeområdet i rommet ble fanget inn sett fra samme synsvinkel som jeg hadde inntatt. Det ble brukt mikrofon fastmontert på kamera. Det ble også senere gjort en del supplerende opptak med håndholdt kamera for å komme tettere på og for å kunne følge barna omkring i rommene. Her ble jeg mer involvert som observatør. Barna tok gjerne kontakt med meg og viste interesse for kamera i større grad. Derfor ble disse observasjonene noe mer oppstykket. Observasjonene ga et datamateriale på til sammen ca. 20 timer med videoopptak i tillegg til feltnotater.

Materialet ble først gjennomgått i sin helhet med tanke på å identifisere overordnede mønstre i hvordan relasjonene mellom barna utfoldet seg. Ett av fenomenene som ble identifisert, var spenninger og konflikter som oppsto mellom de eldste barna i det som jeg velger å kalle utprøvinger av å skape private relasjoner. Slike episoder ble hentet ut i korte filmsekvenser som ble spilt av gientatte ganger på ulik hastighet og etter hvert transkribert i detalj. Tolkningen av disse episodene ble gjort i tråd med en fenomenologisk-hermeneutisk tradisjon (Dahlberg, Dahlberg \& Nyström, 2008) som en veksling mellom å betrakte de små detaljene på mikronivå og hele episoden $\mathrm{i}$ kontekst.

Tolkningene av episodene ble sammenholdt med andre feltnotater, giennomgått og drøftet med personalgruppene og medforskere i tillegg til å bli holdt opp mot mønstre fra andre lignende case-studier. På denne måten innfrir studien kravene om pålitelighet som normalt stilles til god etnografisk forskning (Creswell, 2008). 


\title{
Etiske vurderinger
}

De etiske hensynene knyttet til undersøkelsen er grundig gjennomgått og fremlagt for Norsk senter for forskningsdata (NSD) for godkjenning. Å forske på små barn som ikke selv aktivt kan samtykke til å delta, krever betydelig involvering fra foreldre. I tillegg til å innhente den påkrevde godkjenningen fra dem, har foreldrene vært invitert inn til å følge prosessen tett underveis. Jeg deltok blant annet på foreldremøter i forkant og underveis i prosjektet. I samråd med personalet ga jeg da foreldrene anledning til å se og kommentere utsnitt av datamaterialet etter at feltarbeidet ble avsluttet. Dette har bidratt til at de hele veien har hatt innsyn i måten barnas integritet er ivaretatt på, selv om videoklippene jeg viste dem var korte og av generell og konfliktfri karakter. I samtaler med foreldre og personalgruppene har det for øvrig vært viktig å omtale de konfliktene jeg observerte som normale hendelser i en institusjonshverdag. Det er ikke nødvendigvis hendelser som kunne vært stoppet og sanksjonert av personalet, og de er derfor heller ikke hendelser noen skal lastes for. Å analysere også disse hendelsene er helt nødvendig for å forstå hvordan interaksjonene blant barna arter seg, og det trenger ikke medføre noen form for blottstillelse av hverken barna eller de voksne som er etisk problematisk. Jeg har i den forbindelse støttet meg til den etnografiske metodelitteraturens påpekning av at å fortolke barnas egne uttrykk i seg selv kan kalles et etisk valg (Kampmann, 2003, s. 175). A være tett på konflikter innebærer å gi barna en stemme også om det som er krevende i barnehagehverdagen.

\section{"Vil du være med meg hjem?» - å skape en privat relasjon}

Det er leketid på morgenen i BH2, og alle barna er samlet på basen. Nye barn kommer stadig inn for å orientere seg i rommet og blant de andre barna som er i gang med lek.

\begin{abstract}
Åse på 2 år har med seg en rosa plast-ponni. Hun holder den tett inntil brystet da Trine på samme alder kommer inn $i$ rommet. Ase går bort til Trine og holder ponnien frem med begge hender. «Kan jeg se på den?» spør Trine. "Bare litt», svarer Ase og lar Trine holde $i$ ponnikroppen mens hun selv holder fast $i$ hodet. De står tett sammen og ser på ponnien en kort stund, til en ansatt kommer bort. "Den må du legge $i$ hyllen», sier hun. Ase gir uten protester fra seg ponnien, og den ansatte plasserer den på toppen av en bokhylle utenfor rekkevidde for barna, men fullt synbar. Der står det allerede fire-fem andre plastdyr $i$ ulike farger av samme type. Det er Ase som eier alle sammen.
\end{abstract}

I en institusjonskultur som har klare regler mot å bringe med seg egne leker (Johansson, 2001; Nilsen, 2000), er nok dette en velkjent situasjon. Her håndheves denne regelen, men det virket som om den allikevel stadig ble brutt av den samme jenta. Relasjoner mellom små barn er knyttet til felles aktiviteter på steder og med gjenstander som til enhver tid er tilgjengelig for alle (som beskrevet av Alvestad, 2010; Corsaro, 2014; Nilsen, 2000). Det faktum at relasjoner oppstår spontant som et resultat av midlertidig eierskap til steder og ting, medfører at disse $i$ en 
barnehagekontekst er mer utsatt enn relasjonene etablert i hjemmene hvor en av partnerne har et stabilt eierforhold til stedet og tingene. Åses bruk av ponnien giør det mulig å få en bedre forståelse for hvorfor barn vil forsøke å ta med seg ting hjemmefra, og det er mange faktorer som kan spille inn (Nilsen, 2000, s. 340 ff.). Det kan ses på som en identitetsmarkør for Åse. Ponnien fortalte omgivelsene noe om hvem Åse var, og i denne situasjonen kan den forstås som en identitetsmarkør for Åses og Trines felles interesse for disse figurene. Private leker kan også være en måte å få kontroll over en relasjon på fordi det bidrar til å giøre den mer forpliktende, stabil og i en viss forstand privatisert. I observasjonen over kan introduksjonen av den medbrakte ponnien forstås som en måte å forsterke båndet til Trine på fra Åses side. For Trine var det å få holde ponnien et personlig lån. Det er nærliggende å tolke dette som en sterkere overenskomst mellom de to jentene enn det hadde vært om ponnien hadde vært en del av barnehagens felleseie.

I andre observasjoner i samme gruppe fremgår det at disse to jentene ofte ga inntrykk av å ønske å holde på med det samme, være på de samme stedene og få tilgang til de samme barnehageansatte. Relasjonen så ut til å bli forsterket ved at den ene brakte med seg eksklusive leker som den andre fikk del i. Tilsynelatende ble limet mellom dem sterkere enn om vennskapet bare var basert på eierløse gjenstander i barnehagen. Når de to jentene var sammen om gjenstander som tilhørte barnehagen, virket det som om andre barn i større grad anså aktiviteten som tilgjengelig for flere og tok kontakt. Private gjenstander er med andre ord en verdifull ressurs i en barnehagegruppe.

$\AA$ A forsøke å gjenvinne kontroll over en relasjon blir også demonstrert i en situasjon hvor Åse og et par andre jenter, deriblant Trine og Guro, hadde deltatt i lek med koppestell ved et bord sammen med en assistent og flere andre barn som kom og gikk. Da Åse reiste seg og med høye rop forsøkte å gi tegn til de andre jentene om at leken skulle fortsette et annet sted, valgte de to andre å forlate bordet $\mathrm{i}$ en annen retning. Det utviklet seg til en situasjon hvor disse tre ble løpende etter hverandre uten at de landet $i$ en bestemt aktivitet.

Åse loper trippende på tå, med ponnien høyt hevet over hodet med den ene armen. «Hvem vil preve å ta den", synger hun gjentatte ganger ut i rommet. Mellom hver gang hun synger, ser hun seg omkring, tripper frem og tilbake - hele tiden med ponnien høyt hevet.

Hennes intense og syngende anstrengelser for å skape oppmerksomhet omkring ponnien kan tolkes som et forsøk på å gjenvinne kontroll over en situasjon hvor de andre jentene trakk aktiviteten i en uforutsigbar retning. Private gjenstander dukket opp, og Åse så ut til å vite av erfaring at å invitere til aktivitet med disse, kunne gjenopprette mer stabile relasjoner.

I en annen situasjon et par dager senere var det en liten veske Åse hadde med seg. Hun hadde fått den på en reise, og de ansatte kalte det Paris-veska, noe som indikerer at den var delvis akseptert som en del av barnehagens hverdagsliv. Åse spurte hvem av venninnene som ville ha den, og begge svarte bekreftende i munnen 
på hverandre. Denne gangen valgte Åse å trekke tilbudet tilbake. «Ingen får den", sa hun. Åse hadde nok allikevel fått bekreftet de andres ønske om å få låne veska, og den private gjenstanden var i stand til å påkalle deres oppmerksomhet. De avbrøt det de holdt på med og vendte seg mot Åse. Hennes aktive bruk av ponnien og veska kan forstås som en måte å etablere rom for mer private relasjoner for seg selv, de medbrakte tingene og spesielt utvalgte andre. Det betyr ikke at barnehagens leketøy er uegnet for å bli brukt i slike forhandlinger, og ikke minst Alvestads (2010) forskning viser det tydelig. Det kan allikevel se ut som om private ting har en mer kraftfull betydning i slike forhandlinger.

Privatsfærens betydning for å stabilisere vennskap kan også gi seg andre utslag i samspillet mellom barna.

Åse står og ser på at Trine og Guro lager en dukkeseng med en kasse og noen tepper. De brer over dukken som ligger $i$ kassen. A se roper høyt: "Dere kan få lov til å bli med hjem til meg». Så går hun bort til de to etter tur og gjentar invitasjonen med lavere stemme tett inntil ansiktet deres. De andre svarer ikke, men hun blir med $i$ leken $i$ en kort periode, for hun trekker seg unna og lager sin egen dukkeseng av en annen kasse et par meter unna.

Åses invitasjon om å få være med henne hjem er her en nøkkel til å få delta i leken. Å invitere andre med seg hjem kan tilsynelatende være et kraftfullt virkemiddel for å støtte og stabilisere vennskap mellom barna. Randi Dyblie Nilsen påpeker at private ting ikke trenger å være fysisk tilstede for å kunne spille en rolle, men at de også kan være en symbolsk ressurs for barna i barnehagen (Nilsen, 2000, s. 342). Det kan komme til uttrykk ved at barna gir løfter om å ta med seg bestemte ting neste dag, eller som i Åses tilfelle, å invitere andre hjem til seg for å få del i disse tingene. Både Trine og Guro visste sannsynligvis på den ene siden at en slik invitasjon neppe betydde at de faktisk fikk være med Åse hjem den dagen, men på den andre siden var det et uttrykk for et ønske om å forsterke relasjonene med Trine og Guro utover det barnehagen kunne legge til rette for. Åses eksklusive private sfære ble en symbolsk ressurs som skapte et øyeblikks sterk intimitet mellom dem. Det kan ses i hvor tett fysisk Åse var på de to andre da hun inviterte. Slike kroppslige uttrykk for eksklusiv intimitet er med andre ord en del av barns sosiale repertoar med betydning for utprøvingen av mer stabile relasjoner på den offentlige arenaen som institusjonen er. Hvisking som krever at ansiktet legges helt inntil den andre, danner et privat rom i det åpne rommet hvor ellers alle hører alt.

Slike hviskende invitasjoner, både om å være med hjem eller å få del i private leker, intimiserte forbindelse mellom barna selv om de ikke ble gjennomført. De forsterket relasjoner som ellers kunne ha forblitt relativt flyktige. En kan kalle dette for en privatiserende praksis mellom barna i barnehagen siden de forsøker å trekke inn privatsfæren tilsynelatende for å bøte på usikkerheten i barnehagens vennskapsrom der alt er til låns, eid av og tilgjengelig for alle.

Dette fører som eksemplene viser til implisitte ekskluderinger av de som ikke får del i private leker, ikke blir hvisket til og ikke blir invitert hjem i disse situasjonene. Det finnes derimot andre mer eksplisitte måter å ekskludere på. 


\title{
«Du får ilkke vare med» - å beskytte en privat relasjon
}

Det er frilek kort tid før rydding og aktivitet i BH1, og Astrid, som har en høy status i gruppa, leker alene. Hun er med andre ord tilgjengelig for andres tilnærmelser.

\begin{abstract}
Astrid på 3 år kommer trillende på en dukkevogn. Bak henne går Louise på 2 med et teppe $i$ hånden. Astrid stopper opp og ser etter at dukken sitter fint $i$ vognen. Louise forsøker å legge teppet sitt over dukken, men Astrid tar det av og kaster det på gulvet. Louise plukker det langsomt opp og forlater rommet.
\end{abstract}

Louises initiativ overfor Astrids lek ble avvist, og forsøket på å etablere en relasjon lyktes ikke. Louises måte å tilnærme seg Astrid på var å tilby en tjeneste for Astrid og dukken ved å gi teppet sitt til dukken som satt naken i vognen. Dette er nok erfaringsmessig et velfungerende handlingsvalg, og det er flere forskningseksempler som på ulike måter beskriver støttende og hjelpende adferd mellom barn i denne alderen (Johansson, 2001, s. 55; Tomasello, 2009). I feltnotatene er det andre eksempler på barn i 2-årsalderen som fikk tilgang til andres lek ved å se seg ut det rette øyeblikket for å yte en eller annen form for hjelp eller løse et problem slik at leken kunne tas videre. Hvis et duplo-byggverk stoppet opp fordi en vital bit manglet, kunne observatører trå til. Dersom de bidro til å løse problemet og byggingen kunne gjenopptas, var ofte veien kort til full deltagelse i leken. I dette tilfellet var Louises tjeneste ikke nok for å få innpass. Litt senere møter vi Astrid og Louise igjen, men denne gangen dukker Mina opp.

Astrid sitter på huk og ordner med dukken $i$ vogna. Bak henne står Louise, fortsatt med teppet $i$ hånda. Da kommer Mina bort til dem, hun stiller seg først en halvmeter fra dukkevognen. Så tar hun et steg narmere. Astrid ser på henne og dytter henne lett $i$ magen så hun trekker seg litt unna. Louise, som står bak Astrid, skyter like etter hodet frem og stikker ut tungen med en geipende, høy lyd mot Mina. Mina snur seg og går ut av rommet. Så forsøker Louise på nytt å legge teppet sitt over dukken $i$ vogna. Astrid tar det nok en gang av igjen.

Louises fremstøt mot Astrids dukkelek førte ikke frem første gang, men så dukket Mina opp som også giorde forsøk på å nærme seg leken. Det kan se ut som om Louise resolutt gikk inn i rollen som forsvarer av Astrids lek, selv om dette er en lek hun selv ikke hadde fått innpass i. Louise kunne ha valgt å knytte seg nærmere Mina siden de begge ble avvist av Astrid, men Astrid så fortsatt ut til å være en foretrukket lekepartner for Louise. Mina ble avvist med dytting og geiping fra både Astrid og Louise og valgte å forlate rommet. Først da tok Louise et nytt initiativ mot leken med dukkevogna. Kanskje hadde hennes valg av side i konflikten med Mina gitt uttelling, men alliansen med Astrid i forsvaret av leken var ikke nok til å få del i den eller etablert en vennskapsrelasjon. Hun ble avvist enda en gang.

Dyttingen og geipingen er velkjente nonverbale uttrykk for et ønske om å holde andre på avstand. Det kan handle om makt og dominans (Gulløv, 1999, s. 163 ff.; Johansson, 2001, s. 77). Astrids valg av denne strategien kan riktignok også tolkes som et forsvar av en lek hun selv har påbegynt og ville ha kontroll over. Louises valg 
kan forstås som et ønske om å inngå i Astrids lek. Det var altså en handling som hadde samme sosiale funksjon som å tilby teppet sitt til den nakne dukken, å hjelpe. At geipingen eventuelt medførte negative følelser for Mina i situasjonen, er derfor ikke nødvendigvis en del av Louises intensjon. Hun inviterte seg selv inn i Astrids lek ved å yte hjelp slik andre barn leter frem den vitale manglende biten til andre barns duplo-byggverk.

På samme måte som å legge hodene tett inntil hverandre og hviske, kan slike forsøk på alliansebygging som Louise her forsøkte på, være en måte å skape en mer privat relasjon i det store åpne offentlige rommet. Veien inn i relasjonen skulle være et tilbud om å yte en tjeneste, en strategi som ofte lykkes. For å beskytte slike små private øyeblikk er det nødvendig å utvikle et kroppslig og etter hvert også verbalt repertoar for å sette opp grenser mot andre. For Astrid var den private relasjonen mellom henne selv og dukken. Hun hadde sine måter å avvise begge de to andre jentene på. For deres del handlet situasjonen etter hvert om der og da å kunne håndtere å bli avvist av Astrid. Situasjonen som er beskrevet sier derimot ingenting om hvilke relasjoner som var mulig å oppnå for disse jentene over tid.

\section{Relasjoner i spenningen mellom det offentlige og det private}

Barn under 3 år i barnehage viser ofte sosiale samhandlingsmønster preget av herog-nå-relasjoner knyttet til å dele affektive opplevelser, lekesteder og materiell med andre for en tid (Engdahl, 2011; Greve, 2009; Howes, 2009; Løkken, 2000b). Slike åpne sosiale hendelser ser ut til å skape en atmosfære av spenningsløs flyt i en småbarnsavdeling hvor barna stadig inviteres inn og ut av ulike konstellasjoner (Michélsen, 2004). Barnehagen inviterer i en viss forstand til et slikt sosialt liv. Siden de eierløse lekestedene og tingene er tilgjengelig for enhver i rommet, fremmes et samhandlingsmønster hvor barna også til enhver tid gjør seg tilgjengelig for og er forberedt på å forholde seg til hverandre. Dette velger jeg å kalle barnehage som en offentlig arena.

På denne offentlige arenaen foregår det hele tiden ulike samtidige prosesser siden barnas hverdag er preget av mye selvregulert aktivitet eller frilek. Det er likevel en hel rekke normative forventninger innvevd i barnehagens struktur og pedagogiske tenkning som også gjør seg gjeldende i den såkalte frie leken. Det gjelder ikke minst en sinnrik orden på steder, tider og ting (Ehn, 1983, s. 72 ff.). Derfor er også barnas handlinger i denne offentligheten preget av motstand og ulike forsøk på å få en viss kontroll over sitt hverdagsliv (Markström \& Halldén, 2009; Nilsen, 2000). I tillegg foregår det kontinuerlige forhandlinger barna imellom om hvordan de kollektivt eide ting og steder skal brukes og av hvem (Alvestad, 2010).

De to situasjonene som er analysert i artikkelen, beskriver hvordan de eldste i en småbarnsavdeling etter hvert prøver ut et handlingsrepertoar som åpner for mer stabile og eksklusive relasjoner. Slike relasjoner kan forsøksvis kalles private fordi de er knyttet til handlinger som å hviske, komme tett inntil hverandre og dele ting eller 
løfter om ting som ikke alle kan få del i. Det tilsvarer langt på vei Randi Dyblie Nilsens begrep vi-fellesskap (Nilsen, 2015, s. 63), eller Eva Johanssons uttrykk «att dela lekvärldar» (Johansson, 2001, s. 72). Å kalle det private relasjoner åpner for en noe annen forståelse for situasjonene.

Å kalle relasjoner mellom barn i barnehagen private er riktignok utfordrende fordi det kan skygge for det faktum at det fortsatt er relasjoner som lever seg ut innenfor en stram institusjonell ramme. Dessuten vil valg av begrepsbruk alltid medføre at andre mulige forståelser av situasjoner kan bli borte. I de beskrevne situasjonene er det for eksempel mulig at forhold som makt og ønske om kontroll ikke kan beskrives godt nok. Når jeg likevel velger å kalle disse relasjonene private, er det fordi det gjør det mulig å forsøksvis trekke noen linjer fra de yngste barnas møte med institusjonslivets offentlighet til allmenne sosiale forhold uavhengig av alder og kontekst. Det dreier seg om viktigheten av å kunne vite hvilke relasjoner, steder og ting som er tilgjengelige og offentlige og hvilke som er utilgjengelige og private. Det innebærer også en ansats til en diskusjon om hva ulike typer offentlighet gir av handlingsrom for å etablere mer private relasjoner. Barnehagen som kontekstuell ramme gir noen bestemte betingelser, og sentralt i dette står barnas bruk av leketøy.

Jeg har tidligere nevnt forskning som viser hvordan selv små barn etter hvert kan få en god forståelse for forskjellen mellom privateide og felleseide leker (Johansson, 2001, s. 62), Det er naturligvis forskjell på å ha eierforhold til ting eller steder og å ha en privat relasjon. Vi eier ikke hverandre når vi snakker fortrolig sammen. Det kan allikevel synes som om barns relasjoner til hverandre, tingene og stedene er vevet sammen. Når Corsaro peker på barns behov for å beskytte relasjoner, omtaler han dem som "defenders of interactive space» (Corsaro, 2014, s. 159). Å være venner er uløselig forbundet med å dele aktiviteter, ting og steder, og de som trenger seg på, oppleves ifølge Corsaro som "a threat to the community they have established» (2014, s. 159). En privat relasjon forutsetter med andre ord at eierforhold til ting og steder er avklart. Hvordan kan barn kjenne igjen en relasjon som de ikke skal blande seg inn i, og hvordan kan de selv etablere og beskytte slike relasjoner? Analysene av de to refererte observasjonene gir noen svar, og tingene og stedene spiller en avgiørende rolle.

Å etablere og beskytte private relasjoner ser ut til å kreve en evne til å kompensere for flyktigheten og åpenheten i barnehagerommet. Jeg har beskrevet to mulige handlingsvalg: bruk av medbrakte private gjenstander uten den samme eierløse statusen resten av materiellet har og løfter om å få komme hjem til hverandre og få innpass i hverandres private rom. Private gienstander til bruk i leken eller private rom som symbolsk verdi i interaksjonene er en verdifull ressurs i barnegruppen med makt til å etablere private relasjoner med begrenset adgangsmulighet for andre. Samtidig settes det opp grenser mot det offentlige livet utenfor som beskyttes på ulike måter både fysisk og verbalt. I datamaterialet er det i tillegg til de refererte situasjonene også eksempler på bruk av leketøy som grensemarkører omkring den private leken, slik også Corsaro (2014) finner eksempler på i sin forskning. Nilsen viser til hvordan noen av stedene i den barnehagen hun observerte, slik som en hems, fungerte som 
private rom hvor det ikke var innsyn og ikke tilgang for flere enn et par barn av gangen. Dette var ikke bare et sted for tilbaketrekning fra fellesskapet, men også et sted for det hun kaller illegal aktivitet (Nilsen, 2000, s. 276). Det er altså de stedene hvor barnehagens institusjonelle makt ikke gjør seg så sterkt gjeldende.

Å kunne vite hva som er en privat relasjon og hva som er del av en offentlighet $\mathrm{i}$ barnehagen, krever at barna aktivt prøver ut grensene rundt andre barns aktivitet for å se hvor det er tilgang og hvor de møter motstand. Det er dette Mina og Louise på hver sin måte demonstrerte da de nærmet seg dukkeleken til Astrid. For å prøve om det gis adgang eller ikke, kan de også vise hjelpende adferd overfor hverandre. De kan blant annet, som Louise, prøve å beskytte andres private relasjon for å finne en vei inn for seg selv.

Barnehagen er den første offentlige arenaen barna beveger seg ut på og det første stedet å orientere seg i spenningen mellom det offentlige og det private. Barnehagen er preget av mye tid til selvvalgt aktivitet i åpne rom med materiell som er eid av fellesskapet, og det er derfor et krevende sted å etablere eller forhandle frem små rom for private relasjoner. Det er krevende fordi de skal etableres i rom og av materiell som er like tilgjengelig for alle, og denne eierløse tilstanden gjør det vanskelig for barn å bli oppmerksomme på og ta hensyn til andres private soner. Allikevel gir, for å sitere Torgeir Alvestad, slike utfordringer «... også en betydelig mulighet med hensyn til å kunne bidra til de yngste barnas læring av forhandlingskompetanse» (Alvestad, 2010, s. 136).

En slik institusjonsbeskrivelse gir grunnlag for å forstå barnas adferd $\mathrm{i}$ barnehagen på nye måter. At barn, på tross av forbud, tar med seg private leker og bruker de aktivt som ressurs i forhold til andre og at barn lærer seg å beskytte de relasjonene de inngår i, også med dytting og geiping, kan sies å være nødvendige og uunngåelige fenomen i en institusjonskontekst. Det vil også si at å bli holdt unna, geipet til eller dyttet i en del situasjoner, også til en viss grad er uunngåelig i en barnehage. Å invitere andre barn hjem er handlingsvalg med den samme sosiale betydning. Det handler om å etablere og beskytte eksklusive private relasjoner i en ellers åpen og flytende offentlighet.

Disse måtene å forstå barns adferd i barnehagen på er gjort mulig ved at en tradisjonell begrepsbruk nyanseres og suppleres. Kompleksiteten i relasjonene barna imellom kan ikke beskrives godt nok bare ved bruk av vennskapsbegrepet. Denne artikkelen har forsøkt å beskrive det som barns utprøvinger av et helt nødvendig sosialt handlingsrepertoar innenfor en bestemt institusjonskontekst. Barna må kunne håndtere rollen som aktør på en åpen og flytende offentlig arena og samtidig kunne etablere og beskytte ulike private relasjoner på legitime måter. I tillegg inkluderer dette repertoaret evnen til å kunne gjenkjenne og respektere andres private relasjoner. Dette kan forhåpentligvis være nye analytiske verktøy som kan utvide vår forståelse av hva det innebærer å være barn i en institusjonskontekst.

\section{Avsluttende bemerkninger og praktiske konsekvenser}

Barnehagen er et sted for utvikling av sosial kompetanse. Det er nedfelt som et tydelig mål i rammeplanen, og flere barnehager gir foreldre såkalte vennegarantier. Det er 
derfor viktig å være oppmerksom på hvilke sosiale prosesser institusjonen setter i gang i kraft av å være et sted med mange barn som skal dele på felles ting i et felles rom.

Denne artikkelen har vist at dette giøres gjennom ulike handlingsvalg. Bruk av private gjenstander og løfte om besøk hjem er for eksempel en verdifull ressurs som kan privatisere og dermed forsterke en relasjon. Et annet handlingsvalg er ulike former for ekskluderingsmekanismer og allianseinngåelser. Felles for begge disse handlingsmønstrene er at det er adferd som ofte sanksjoneres i barnehagen, men som ikke desto mindre trigges av kvaliteter ved barnehagen som institusjon - preget som de er av store barnegrupper som skal etablere relasjoner omkring lek med eierløse ting. Barnehagen er med andre ord en offentlig arena der barn etter hvert må kunne etablere og ivareta private relasjoner av varierende varighet og dybde.

Det betyr at det å kunne håndtere avvisninger, også er en del av den sosiale læringsprosessen som finner sted $i$ en institusjonskontekst og som uansett kontekst er nødvendig. Vi opplever alle situasjoner daglig hvor vi må respektere at det oppstår samtaler og aktiviteter omkring oss som vi ikke skal blande oss inn i. På samme måte har vi selv et behov for å inngå i relasjoner som krever at vi blir private og trekker oss ut av offentligheten for en stund. Dette er et handlingsrepertoar barn må prøve ut.

Det kan være faglig utfordrende for praksisfeltet å forholde seg til disse tidligste utprøvingene av å etablere eksklusive relasjoner og tette dyader fordi det unektelig oppstår sosiale spenninger når leker smugles med hjemmefra, løfter om besøk hjem blir gitt og tatt tilbake eller andre barn blir avvist fra å delta i lek med fysisk makt. Samtaler med personalet i forbindelse med feltarbeidet ga et inntrykk av at begge de situasjonene som beskrives i artikkelen, er situasjoner som ville blitt stoppet og sanksjonert av personalet om de hadde vært sett.

Å bringe fram ny kunnskap om hvilken rolle disse handlingsvalgene spiller i barns måte å orientere seg sosialt i en institusjon på, har ikke som mål at personalet slutter å kjenne på ubehaget med å se hvor utfordrende en hverdag i barnehagen kan være for barn. Men det vil forhåpentlig kunne medføre en mer hensiktsmessig måte å respondere og veilede barn på når de opplever at noen relasjoner er utilgjengelige og når de prøver ut måter å beskytte relasjonene sine på. Ikke minst kan det medføre mer refleksjon omkring hva eventuelle forbud mot medbragte leker innebærer og hva som kan være barns motivasjon for å omgå disse bestemmelsene.

\section{Biografi}

Dag Øystein Nome arbeider som førsteamanuensis i pedagogikk ved Universitetet i Agder. Han er utdannet førskolelærer og har arbeidet i 25 år i skole og barnehage. Han har i tillegg spesialkompetanse som Steinerpedagog og er gjestelærer ved Rudolf Steinerhøyskolen i Oslo. Nome har doktorgrad på barn-barn-relasjonene på småbarnsavdelinger, og han har skrevet flere artikler og bokkapitler blant annet om lek.

\section{Referanser}

Alvestad, T. (2010). Barnehagens relasjonelle verden - små barn som kompetente aktører $i$ produktive forhandlinger.

(PhD-avhandling). University of Gothenburg. Faculty of Education, Göteborg.

Corsaro, W. (2014). The sociology of childhood. London: SAGE publications. 
Creswell, J. W. (2008). Educational research: planning, conducting, and evaluating quantitative and qualitative research. Upper Saddle River, N.J.: Pearson.

Dahlberg, K., Dahlberg, H. \& Nyström, M. (2008). Reflective lifeworld research. Lund: Studentlitteratur.

Ehn, B. (1983). Ska vi leka tiger?: daghemsliv ur kulturell synvinkel. Stockholm: LiberFörlag.

Engdahl, I. (2011). Toddlers as social actors in the Swedish preschool. Early child development and care, 181(10), 1421-1439.

Greve, A. (2009). Vennskap mellom små barn i barnehagen. Oslo: Pedagogisk forum.

Gulløv, E. (1999). Betydningsdannelse blandt børn. København: Gyldendal.

Howes, C. (2009). Friendship in early childhood. IW. M. Bukowski, K. H. Rubin, B. Laursen (Red.), Handbook of peer interactions, relationships, and groups (s. 180-194). New-York: The Guildford Press.

Johansson, E. (2001). Små barns etik. Stockholm: Liber AB.

Kampmann, J. (2003). Etiske overveielser i etnografisk børneforskning. I E. Gulløv \& S. Højlund (Red.), Feltarbejde blandt børn (s.167-183). København: Gyldendal.

Kunnskapsdepartementet. (2013). Fremtidens barnehage (Vol. nr 24 (2012-2013)). Oslo: Departementenes servicesenter, Informasjonsforvaltning.

Løkken, G. (2000a). The playful quality of the toddling "style". International fournal of Qualitative Studies in Education, 13(5), 531-542.

Løkken, G. (2000b). Toddler peer culture: the social style of one and two year old body-subjects in everyday interaction. (PhD-thesis), Norges teknisk-naturvitenskapelige universitet, Trondheim.

Markström, A. M. \& Halldén, G. (2009). Children's strategies for agency in preschool. Children Eீ society, 23(2), 112-122.

Michélsen, E. (2004). Kamratsamspel på småbarnsavdelningar. (PhD-avhandling). Stockholms universitet, Stockholm.

Nilsen, R. D. (2000). Livet i barnehagen: en etnografisk studie av sosialiseringsprosessen (PhD-avhandling). Fakultet for samfunnsvitenskap og teknologiledelse, Pedagogisk institutt, Norges teknisk-naturvitenskapelige universitet, NTNU.

Nilsen, R. D. (2015).Vi-fellesskap i barnehagen. I A. Greve, M. Øksnes (Red.), Vennskap. Barndom i bernehagen (s. 61-81). Oslo: Cappelen Damm Akademisk.

Rammeplanen for barnehager. (2017). Rammeplan for barnehagens innhold og oppgaver. Hentet fra: https://www. udir.no/laring-og-trivsel/rammeplan/revidering-av-rammeplan/

Steenbuch, B. (2016, 24.08.). Forskere: Ikke styr barnas lek for mye. Aftenposten. Hentet fra: http://www.aftenposten.no/osloby/Forskere-Ikke-styr-barnas-lek-for-mye-602406b.html

Størksen, I. (2007). Barnet i barnehagen: relasjoners betydning for tidlig utvikling. I Barna våre - $i$ går, $i$ dag, $i$ morgen. Oslo: Frelsesarmeen.

Tomasello, M. (2009). Why we cooperate. Cambridge, Mass: The MIT Press.

Øksnes, M. \& Greve, A. (2015). Barndom i barnehagen:Vennskap. Oslo: Cappelen Damm Akademisk. 